6. Burbach R, Nunez O, Kagarlitsky O. Globalization and its Discontents, The Rise of Postmodern Socialisms. London, 1997. - $196 \mathrm{p}$.

7. Carment D., James P. Internal Constraints and Interstate Ethnic Conflict // Journal of Conflict Resolution. March 1995. - Vol.39. \# 1. - P. 82-109.

8. Cvetkovich A, Kellner D. Introduction: Thinking Global and Local / Cvetkovich A., Kellner D., eds. Articulating the Global and the Local Globalization and Cultural Studies. - Boulder, 1997. - $258 \mathrm{p}$.

9. Hale H.E. Statehood at Stake: Democratization, Secession and the Collapse of the USSR. Cambridge, 1998. 243 p.

10. Hobsbawm E. The nation and globalization // Constellations. 1998. - Vol. 5. \# 1. - P. 1-9.

11. Horowitz D. Ethnic Groups in Conflict. Berkeley, 1985. - 697 p.

12. Kellas J. The Politics of Nationalism and Ethnicity. New York, 1991. P. 39-49.

13. Laitin D.D. Identity in Formation: the Russian-speaking populations in the near abroad. - Ithaca, 1998. - 417 p.

14. Meernik J. United States Military Intervention and the Promotion of Democracy. Journal of Peace Research. 1996. - Vol. 33. \# 4. - P. 391-402.

15. Хенкин С. Сепаратизм в России - позади или впереди? // Pro et Contra. 1997. Т.2. №1. С. 27-43.

DOI 10.31558/2617-0248.2020.5.10

удК 340.116

\title{
РОЛЬ ГРОМАДЯНСЬКОГО СУСПІЛЬСТВА У ПРОЕКТУВАННІ ПУБЛІЧНОЇ ПОЛІТИКИ В УКРАЇНІ
}

ORCID ID: https://orcid.org/0000-0003-3922-7619

Чальцева О.М., д. політ. н., завідувач кафедри Донецького національного університету імені Василя Стуса

Процес інституціоналізації громадянського суспільства в Україні як одного з головних акторов публічного поля політики має свої специфічні особливості, які впливають на якість публічного капіталу та стан політичної системи.

Кризові явища в політичній системі України, які призвели до зміни влади, сплеску громадянської активності та появи нових форм взаємодії публічних акторов, актуалізували питання аналізу та моніторингу громадянського сектора в державі та визначення його ролі у формуванні публічної політики.

Процес інституціоналізації громадянського суспільства в українському публічному просторі проходить у тісному взаємозв'язку з державними інститутами, які також структурно і функціонально змінюються, втрачаючи традиційні функції і піддаючись інноваціям. Інституціональні перетворення запускають механізми змін у системі взаємин акторов і форматують нові практики співпраці. Складні та фрагментовані взаємодії державних і недержавних інститутів (нових і тих, що реформуються) публічної політики створюють множинність мережевих практик співпраці і формують публічний капітал сучасної політичної системи України.

Формування нової моделі публічної політики в Україні по траєкторії «знизу - вгору» (інститутами громадянського суспільства) проходить у відповідності з глобальними тенденціями змін інститутів і практик взаємодій акторов політичних процесів, але має суттєві особливості і труднощі. Унікальність українського варіанту полягає в тому, що громадянське суспільство швидше і результативніше інституціоналізується як публічний актор, ніж держава, яка не «встигає» інституціонально підлаштуватися під зміни і в силу обмеженості традицією попередньої управлінської моделі гальмує участь громадського сектору в політичному житті, створюючи імітаційні практики публічності.

Ключові слова: громадянське суспільство, інститути, публічна політика, капітал, громадський сектор.

Chaltseva 0 . The role of civil society in the design of public policy in Ukraine

The process of institutionalization of civil society in Ukraine as one of the main actors in the public field of politics has its own specific features that affect the quality of public capital and the state of the political system.

The crises in the political system of Ukraine, which led to a change of government, a surge in civic activity and the emergence of new forms of interaction between public actors, raised the issue of analysis and monitoring of the civil sector in the country and determining its role in public policy.

The process of institutionalization of civil society in the Ukrainian public sphere takes place in close cooperation with state institutions, which are also structurally and functionally changing, losing traditional 
functions and succumbing to innovations. Institutional transformations trigger mechanisms of change in the system of actor relations and form new practices of cooperation. Complex and fragmented interactions of state and non-state institutions (new and reforming) of public policy create a multitude of network practices of cooperation and form the public capital of the modern political system of Ukraine. The formation of a new model of public policy in Ukraine on the trajectory of "bottom - up" (civil society institutions) is in line with global trends of change of institutions and practices of interaction of actors in political processes, but has significant features and difficulties. The uniqueness of the Ukrainian version is that civil society is faster and more effectively institutionalized as a public actor than a state that does not "have time" to institutionally adapt to change and due to the limited tradition of the previous governance model inhibits public sector participation in political life.

Keywords: civil society, institutions, public policy, capital, public sector.

Для демократичних систем, які орієнтуються на діалогову модель відносин між акторами, головна роль відводиться інституту громадянського суспільства. Роль громадянського сектора в демократичних системах можна визначити як діяльнісну характеристику громадян у публічній взаємодії, яка передбачає: здатність дискутувати й формувати суспільні цінності; здатність формувати позитивний політичний порядок; готовність співпрацювати на горизонтальному рівні, розвиваючи соціальний капітал громадянського суспільства в цілому, а не тільки його окремих груп; змогу взаємодіяти 3 органами державного управління 3 метою підвищення ефективності публічного управління; здатність використовувати й просувати гуманітарні (а не маніпулятивні) технології взаємодії; готовність проявляти протестну активність у межах правового поля.

Аналіз останніх досліджень та публікацій.

Аналіз інституціоналізації громадянського суспільства як актора публічної політики доцільно розглядати через призму неоінституціонального підходу. У 90-ті роки помітно посилилися позиції політичного інституціонального підходу до аналізу динаміки громадської підтримки, який акцентував увагу на інституціональних факторах, а саме на структурі політичних інститутів і їі ролі у визначенні способів вираження громадянським суспільством своєї підтримки або недовіри до влади (Андерсон К., Пауелл Дж. Б., Віттен Г., Найджеб А. та ін.).

Взаємозв'язок держави і громадянського суспільства - це сфера соціологічного неоінституціоналізму, який за допомогою інституціональної методології $\mathrm{i}$ термінології розкриває «наявність стабільних моделей взаємодії, що існують між групами приватного сектора, а також між цими групами й державним сектором. Застосування потужних аналітичних засобів для опису цих зв'язків також примножує значення такого варіанту інституціонального аналізу Пітерс Б.

Представники структурного інституціоналізму (Уівер, Рокман, Прессман, Вілдавські, Іммергарт, Шугарт, Лейпхарт та ін.) дають нам зрозуміти, яким чином публічні інститути, в тому числі громадянське суспільство впливають на публічну політику і як приймаються рішення (теорія «контрольно-пропускних пунктів»). Цей напрямок основний акцент робить на структурно-діяльнісному аспекті публічної політики, де ключова роль відведена структурі інституціональних акторів і механізмам прийняття рішень.

В українські політичній науці проблемам громадянського суспільства присвячені роботи: Гураль П., Колодій А., Степаненко В., Мазуренка Л., Щедрової Г., Червякової О. та ін.

Метою статті $\epsilon$ виявлення специфічних особливостей процесу інституціоналізації громадянського суспільства в Україні як одного з головних акторов публічного поля політики, які впливають на якість публічного капіталу та стан політичної системи у цілому.

Виклад основного матеріалу. В умовах, коли держава як основний інститут перестала бути монополістом у вирішенні політичних і соціальних проблем, реальною потребою стає участь громадськості в політичному управлінні, залучення населення та громадських асоціацій у процес прийняття, здійснення та контролю над прийняттям рішень.

Традиція в політичній науці, яка існувала довгий період часу, представляла громадянське суспільство в інституціональному плані виключно як сукупність громадських об'єднань і некомерційних організацій. Сучасне розуміння громадянського суспільства зводиться до того, що воно представлено в політичному просторі різноманітними i численними інституціями та формами прояву громадянської активності. Громадянське суспільство - це багатогранний i диференційований ансамбль різноманітних інститутів $\mathrm{i}$ суб'єктів - юридичних осіб та незареєстрованих організацій, які здійснюють соціально-корисну діяльність у різних сферах суспільного життя, створюючи умови для самореалізації громадян їх об’ єднань, забезпечення приватних потреб та інтересів, а також, по мірі становлення громадянського суспільства, поступового перерозподілу між громадськими інститутами і державою за вирішення важливих завдань у ході просування принципів партиципаторної демократії та розширення політичної участі [1, с.5-6].

Громадські інститути - це історично певний різновид соціокультурних систем, які характеризуються в цілому горизонтальними й неформальними зв'язками, добровільним типом членства, відкритістю, що встановлює й підтримує організаційні, ціннісно-нормативні та інші межі автономної діяльності й конвенційної взаємодії людей, а також спрямовує їх активність у бік більш ефективної та всебічної актуалізації діяльності 
відповідно до критеріїв громадянськості (цілісність, свобода і самодіяльність) [2, с. 282].

Такий тип інститутів забезпечує горизонтальну взаємодію акторів (зв’язок координації) при домінуючій ролі громадянського суспільства в публічній політиці. Рівень розвитку координаційних зв'язків визначає траєкторію публічної політики «знизу - вгору». Якщо громадянське суспільство інституціонально готове брати участь у процесі прийняття рішень, відповідно, зв'язки координації матимуть інтенсивний характер, а значить, і вплив «публіки» «знизу - вгору» буде продуктивним.

Кризові явища в політичній системі України, які призвели до зміни влади, сплеску громадянської активності та появи нових форм взаємодії публічних акторов, актуалізували питання аналізу та моніторингу громадянського сектора в державі та визначення його ролі у формуванні публічної політики. Аналіз інституціоналізації громадянського суспільства як суб'єкта публічної політики в Україні повинен враховувати наступні фактори:

1. характер змін політичного простору на різних рівнях: глобальному, регіональному, національному;

2. національний політичний простір має конкретно-історичний, системний і дискретний характер;

3. суб'єктність громадянського суспільства визначається специфічною соціокультурною диференціацією політичної ідентифікації українського соціуму;

4. характер і форми взаємодії між інститутами громадянського сектора та іншими суб'єктами політики, залежать від інституціонального оформлення системи соціального партнерства;

5. ступінь організаційної оформленості громадянського суспільства.

Такі глобальні тренди як процеси зміни суб'єктності в публічному політичному просторі i форматування нових інститутів та інституціоналізованих практик взаємодії акторов, спрямованих на співучасть в управлінні, привели дослідників до розуміння того, що публічна політика вже не може бути обмежена тільки електоральними процесами і практиками участі населення у вирішенні питань, які задані політичним порядком денним [3]. Залучення громадян до політичного життя перетворює їх у повноцінних i самостійних акторов, здатних формувати, просувати порядок денний і контролювати ступінь його виконання. Одним з головних показників громадянської самостійності є рівень ії інституціоналізації, завдяки якій роль публічних акторов стає все більш значущою і підвищує їх суб’єктний статус.

Українська держава, перебуваючи в умовах трансформаційних змін, орієнтуючись на глобальні тенденції у сфері управління, намагається адаптувати свої традиційні інститути і стимулювати появу нових інститутів у відповідності з викликами системі ззовні і зсередини. Для забезпечення сталого розвитку і запобігання конфліктності в системі в умовах інстититуціонального реформування, важливим є дотримання принципу горизонтальної інтеграції акторів публічного процесу. Останнє передбачає, що перетворення інститутів соціально-політичної сфери відбувається не ізольовано від публічної сфери та соціально політичних акторов, а навпаки, в тісному просуванні інтересів і очікувань основних агентів публічного поля в політичному просторі, зацікавлених в ефективному функціонуванні даних інститутів [4, с. 20].

Процес інституціоналізації громадянського суспільства в українському публічному просторі проходить у тісному взаємозв'язку з державними інститутами, які також структурно і функціонально змінюються, втрачаючи традиційні функції і піддаючись інноваціям. Інституціональні перетворення запускають механізми змін у системі взаємин акторов і форматують нові практики співпраці. Складні та фрагментовані взаємодії державних i недержавних інститутів (нових i тих, що реформуються) публічної політики створюють множинність мережевих практик співпраці і формують публічний капітал сучасної політичної системи України.

Роль громадянського суспільства у мережевих конструкціях публічного партнерства залежить від рівня інституціоналізації даного виду акторов і від поведінкової стратегії держави по відношенню до суспільства.

Інституалізація громадянського суспільства регламентується правовими нормами (друга категорія законів, що відносяться до громадського сектора, див. у 5.2 ) та прийнятою в 2016 р. Національною стратегією сприяння розвитку громадянського суспільства в Україні на 2016-2020 роки (далі - Стратегія) [5].

Стратегію можна розглядати як складову стратегії сталого розвитку «Україна-2020» схвалену Указом Президента України від 12 січня 2015 р. № 5/2015. В ній зумовлено необхідність створення державою сприятливих умов для розвитку громадянського суспільства, різноманітних форм демократії участі, налагодження ефективної взаємодії громадськості з органами державної влади та органами місцевого самоврядування [217]. Указ Президента України від 26 лютого 2016 р. № 68 «Про сприяння розвитку громадянського суспільства в Україні» [6].

Як зазначає українська дослідниця О. В. Червякова за результатами проведеного аналізу за системою основних чинників самоорганізаційної спроможності, Стратегія є важливим і основним документом для формування і розвитку громадянського суспільства та публічного управління, де добре і чітко визначено умови, як основні проблеми розвитку громадського сектора в Україні, сформовано ідеї, що являють собою мету і принципи Стратегії, а також зазначено технології через стратегічні напрями та завдання з урахуванням реалізації, моніторингу та оцінкою виконання Стратегії. Але відсутність такого чиннику як ресурси і постійного діалогу між інституціями державної та публічної влади унеможливлює реалізацію даної Стратегії на сучасному етапі [7, с. 206].

На фоні досить повільного і запізнілого у часі процесу формування і реалізації стратегії розвитку громадянського суспільства в публічному просторі України, сучасна практика участі громадського сектора 
в політичному житті країни і його організаційний розвиток мають вже свою історичну традицію і певні особливості в організаційному, ресурсному, правовому, структурному, поведінковому плані.

Рівень організаційної оформленості громадянського суспільства є одним з основних показників якості та ефективності даного інституту в процесі формування публічної політики. Згідно Індексу сталості розвитку організацій громадянського суспільства (ОГС) України з 2009p. по 2019p., загальний рівень сталості громадського сектора в цілому покращився, хоча зміни стану даного інституту з 2009 р. мають незначний характер[8]. Див. табл.1.

Таблиця 1

\section{Показники Індексу громадянського суспільства \\ (CSO Sustainability Index for Central and Eastern Europe and Eurasia в Україні у 2009-2014 pp.) (за даними USAID)*}

*1 - консолідований рівень (найвищий), 7 - початковий (найнижчий).

\begin{tabular}{|l|c|c|c|c|c|c|c|c|c|c|c|}
\hline \multicolumn{1}{|c|}{ Показник } & 2009 & 2010 & 2011 & 2012 & 2013 & 2014 & 2015 & 2016 & 2017 & 2018 & 2019 \\
\hline $\begin{array}{l}\text { Сталий розвиток } \\
\text { НуО }\end{array}$ & 3,5 & 3,5 & 3,5 & 3,4 & 3,4 & 3,3 & 3,3 & 3,3 & 3,2 & 3,3 & 3,2 \\
\hline $\begin{array}{l}\text { Правове } \\
\text { середовище }\end{array}$ & 3,6 & 3,6 & 3,5 & 3,5 & 3,4 & 3,4 & 3,4 & 3,4 & 3,5 & 3,6 & 3,5 \\
\hline $\begin{array}{l}\text { Організаційна } \\
\text { спроможність }\end{array}$ & 3,6 & 3,5 & 3,5 & 3,4 & 3,4 & 3,3 & 3,3 & 3,3 & 3,2 & 3,2 & 3,1 \\
\hline $\begin{array}{l}\text { Фінансова } \\
\text { життсздатність }\end{array}$ & 4,2 & 4,2 & 4,3 & 4,3 & 4,2 & 4,2 & 4,2 & 4,2 & 4,2 & 4,1 & 4,0 \\
\hline $\begin{array}{l}\text { Кампанія } \\
\text { громадського } \\
\text { представництва }\end{array}$ & 2,8 & 2,7 & 2,6 & 2,5 & 2,3 & 2,2 & 2,1 & 2,1 & 2,1 & 2,2 & 2,2 \\
\hline Надання послуг & 3,3 & 3,3 & 3,3 & 3,3 & 3,3 & 3,2 & 3,2 & 3,2 & 3,2 & 3,2 & 3,2 \\
\hline Інфраструктура & 3,5 & 3.5 & 3,4 & 3,4 & 3,4 & 3,4 & 3,4 & 3,3 & 3,2 & 3,2 & 3,2 \\
\hline $\begin{array}{l}\text { Ставлення з боку } \\
\text { громадськості }\end{array}$ & 3,8 & 3,7 & 3,6 & 3,6 & 3,5 & 3,3 & 3,3 & 3,3 & 3,3 & 3,3 & 3,3 \\
\hline
\end{tabular}

Джерело: Індекс громадянського суспільства CSO Sustainability Index for Central and Eastern Europe and Eurasia в Україні https://www.usaid.gov/europe-eurasia-civil-society

Організаційна складова формування громадянського суспільства за роки незалежності в Україні представлена достатньо великою кількістю зареєстрованих організацій громадського сектора. Так, за даними Єдиного державного реєстру установ та організацій України, оприлюдненими Державною службою статистики України (далі- Держстат), на 01 березня 2015 р. було зареєстровано 65080 громадських організацій, 25900 профспілок та їх об’єднань, 13800 благодійних організацій, 15786 об’єднань співвласників багатоквартирних будинків та 1363 органів самоорганізації населення [9].

Позитивні зрушення сталися в інституціональній спроможності організацій, диверсифікації джерел фінансування, фінансовому менеджменті, громадському представництві, наданні послуг і ставленні з боку громадськості. Завдяки своїй ролі в Революції Гідності громадянське суспільство стало ідентифікуватись суспільством, державою і політиками як повноцінний гравець, який впливає на розвиток країни [10].

Включеність громадян у політичний процес виражається у різних формах політичної участі. Однією з форм є протестна поведінка. Політичні кризи в Україні, нездатність владних еліт забезпечити позитивні ефекти зворотного зв'язку призвели до алієнації - відчуження українського суспільства від політики, але в той же час- формуванню в окремій його частині усвідомлення неправильності дій керівництва країною i необхідності щось змінювати. В результаті в політичній системі України сформувалася соціально і тематично різноманітна протестна практика участі громадянського суспільства у публічному просторі України, яка стала одним з основних і регулярних способів впливу суспільства на владу.

Протести в Україні в силу своєї регулярності, системності, реактивності перетворилися на повноцінних акторов публічного процесу, розширили практики безпосередньо «вуличної» участі [11]. Такий вид самоорганізації політичних акторов - відповідна реакція на відсутність результатів зворотного зв'язку з владою і ситуативний пошук рішень з питань, які стоять перед незадоволеними групами. В результаті системної перманентної протестної культури сформувалась в Україні, на думку В. Степаненка, революційна публічність, яка з одного боку викрила проблеми взаємодії між суспільством і владою, 
з іншого розкрила можливість для формування нових форм впливу на політику з боку громадянського суспільства [12, с. 60].

Ще одним яскравим прикладом інституціоналізованого актора, який формує публічний капітал «знизу вгору», можна назвати аналітичні спільноти, які виконують експертну, аудиторську та дорадчу функції в українській державі. За даними глобального індексу Global Go To Think Tank INDEX Report в Україні 201420pp. офіційно діє більше 40 аналітичних центрів, які мають свою інтелектуальну репутацію і вносять фрагментарно внесок у політичні рішення держави [13].

Однією з основних проблем для даної категорії акторов в Україні $\epsilon$ проблема підвищення їх суб'єктності і затребуваності в публічному просторі. Найчастіше держава, імітуючи громадську активність, виступає в ролі творця і покровителя експертних структур, механічно виділяючи для них простір у сфері політичних відносин в «потрібний» час і 3 «потрібним контентом», або створює діалоговий майданчик з експертними спільнотами, але в реальній політичній ситуації не використовує рекомендації цих структур. Для підвищення суб'єктності аналітичних спільнот в Україні необхідно забезпечити: публічність політичного процесу, затребуваність реальної аналітичної інформації з боку влади, включеність альтернативних «мозкових центрів» в експертні групи з розробки стратегій розвитку держави.

До позитивних ефектів інституціоналізації публічного капіталу можна також віднести розвиток краудсорсингової і краудфандінгової діяльності в Україні, що сприяє розвитку і використанню політичних інновацій у політичних практиках громадян.

Особливо активно розвивається в публічному полі України IT-краудсорсинг, одна з головних задач якого, впровадження цифрових технологій в управління державою, що дозволяє громадянам бути включеними в процес прийняття рішень є однією з основних умов електронної демократії. IТ-краудсорсинг представлений в Україні численними стартапами, що пропонують інноваційні продукти для розширення публічного простору в мережі. Стартапери працюють над додатками і сервісами на основі відкритих даних, покликаних підвищити конкурентоспроможність України та сприяти розвитку громадянського суспільства [14]. Успішним прикладом $\epsilon$ стартапівський проект громадської організації SocialBoost Стартап «1991 Data Incubator»- за підтримки міжнародних донорів, урядових організацій та інших партнерів [15]. Один із найшвидше зростаючих напрямків краудсорсингу в Україні - це проєктний. Прикладом можуть бути проєкти С-Дата, «007» і Срозслідування, створені за сприяння держави та громадянського сектора для впровадження в політичне поле системи публічних даних про державні фінанси. Розвиток цих проєктів, як різновиди політичного краудсорсина дозволяє інституціювати антикорупційні механізми і за допомогою онлайн-технологій контролювати владу.

Таким чином, формування нової моделі публічної політики в Україні по траєкторії «знизу - вгору» (інститутами громадянського суспільства) проходить у відповідності з глобальними тенденціями змін інститутів і практик взаємодій акторов політичних процесів, але має суттєві особливості і труднощі. Унікальність українського варіанту полягає в тому, що громадянське суспільство швидше і результативніше інституціоналізується як публічний актор, ніж держава, яка не «встигає» інституціонально підлаштуватися під зміни і в силу обмеженості традицією попередньої управлінської моделі гальмує участь громадського сектору в політичному житті, створюючи імітаційні практики публічності.

Однією з основних проблем можна назвати недостатню підготовленість законодавчої бази щодо статусу, прав і обов’язків публічних інститутів громадянського сектора, що відбивається на характері відносин $з$ державними структурами. Політико-правове підгрунтя участі громадянського сектора в публічному процесі необхідно вдосконалювати i адаптувати до сучасних тенденцій розвитку політики i внутрішньополітичним реаліям. Особливої актуальності набувають питання необхідності законодавчого обгрунтування впровадження різноманітних конвенціональних форм участі громадськості в публічному процесі, що сприяє інституціоналізації суб'єктності, підвищенню рівня довіри до публічних акторів.

Особливістю української моделі публічної політики, форматованої «знизу - вгору», є висока протестна активність громадянського суспільства, яка в умовах порушення каналів зворотного зв'язку і низького рівня довіри громадян до політичних інститутів сприяє формуванню та інституціоналізації нових каналів громадянської та політичної участі.

\section{Бібліографічний список:}

1. Оценка состояния и развития гражданского общества в России / Проблемы, инструменты и региональная специфика / Под ред. В.Н.Якимца М.: КРАСАНД, 2010. 200 с.

2. Резник Ю.М. Введение в социальную теорию: социальная системологии. М.: Наука., 2003.525 с.

3. Бебик В. М. Електоральний політичний маркетинг: теорія і міжнародна практика. Освіта регіону. Політологія, психологія, комунікації. 2011. № 4. С. 325-331.

4. Никовская Л.И., Якимец В.Н. О состоянии институтов публичной политики. Власть. 2015. № 6. C. $16-22$.

5. Національна стратегія сприяння розвитку громадянського суспільства в Україні. URL: http://zakon2.rada.gov.ua/laws/show/68/2016

6. Офіційний сайт президента України. URL: http://www.president.gov.ua/ru/content/pub_info.html

7. Червякова О.В. Перехід від державного до публічного управління в умовах розвитку 
громадянського суспільства в Україні. Публічне урядування. Випуск№ 3 (4). 2016. С. 198-206.

8. Індекс громадянського суспільства CSO Sustainability Index for Central and Eastern Europe and Eurasia в Україні. URL: https://www.usaid.gov/europe-eurasia-civil-society

9. Державна служба статистики України. URL: http://www. ukrstat.gov.ua

10. Індекс сталості розвитку громадянського суспільства в Україні/ Творчий центр ТЦК.

URL: http://ccc-tck. org.ua/

11. Чальцева О.М. Роль політичних протестів в публічному діалозі (український і російський досвід).

Гілея: науковий вісник. 2013. Випуск 75 (№ 8). С.480-482.

12. Степаненко В. Политическая публичность в трансформации: дискурсы, символизации и практики в Украине в 2000-х гг. Постсоветская публичность: Беларусь, Украина. Сборник научных трудов под редакцией М. Соколовой, В. Фурса. Вильнюс: ЕГУ, 2008. 224 с. С. 56-76.

13. The Go To Think Tank Index. URL: http://gotothinktank.com/index

14. Деловое издание Hubs. URL: http://hubs.ua/starter/pervy-j-vy-pusk-opan-data-startapov-v-1991-70489.html

15. Інкубатор 1991. URL: http://1991.vc/about/

References:

1. Otsenka sostoianyia y razvytyia hrazhdanskoho obshchestva v Rossyy / Problemы, ynstrumentы y rehyonalnaia spetsyfyka / Pod red. V.N.Yakymtsa M.: KRASAND, 2010. 200 s.

2. Reznyk Yu.M. Vvedenye v sotsyalnuiu teoryiu: sotsyalnaia systemolohyy. M.: Nauka., 2003.525 s.

3. Bebyk V. M. Elektoralnyi politychnyi marketynh: teoriia i mizhnarodna praktyka. Osvita rehionu. Politolohiia, psykholohiia, komunikatsii. 2011. № 4. S. 325-331.

4. Nykovskaia L.Y., Yakymets V.N. O sostoianyy ynstytutov publychnoi polytyky. Vlast. 2015. №6. S.16-22.

5. Natsionalna stratehiia spryiannia rozvytku hromadianskoho suspilstva $\mathrm{V}$ Ukraini.

URL: http://zakon2.rada.gov.ua/laws/show/68/2016

6. Ofitsiinyi sait prezydenta Ukrainy. URL: http://www.president.gov.ua/ru/content/pub_info.html

7. Cherviakova O.V. Perekhid vid derzhavnoho do publichnoho upravlinnia v umovakh rozvytku hromadianskoho suspilstva v Ukraini. Publichne uriaduvannia. Vypusk№ 3 (4). 2016. S. 198-206.

8. Indeks hromadianskoho suspilstva CSO Sustainability Index for Central and Eastern Europe and Eurasia v Ukraini. URL: https://www.usaid.gov/europe-eurasia-civil-society

9. Derzhavna sluzhba statystyky Ukrainy. URL: http://www. ukrstat.gov.ua

10. Indeks stalosti rozvytku hromadianskoho suspilstva $\mathrm{v}$ Ukraini/ Tvorchyi tsentr TTsK. URL: http://ccc-tck. org.ua/

11. Chaltseva O.M. Rol politychnykh protestiv v publichnomu dialozi (ukrainskyi i rosiiskyi dosvid). Hileia: naukovyi visnyk. 2013. Vypusk 75 (№ 8). S.480-482.

12. Stepanenko V. Polytycheskaia publychnost v transformatsyy: dyskursu, symvolyzatsyy y praktyky v Ukrayne v 2000-kh hh. Postsovetskaia publychnost: Belarus, Ukrayna. Sbornyk nauchnblkh trudov pod redaktsyei M. Sokolovoi, V. Fursa. Vylnius: EHU, 2008. 224 s. S. 56-76.

13. The Go To Think Tank Index. URL: http://gotothinktank.com/index

14. Delovoe izdanie Hubs. URL: http://hubs.ua/starter/pervy-j-vy-pusk-opan-data-startapov-v-1991-70489.html

15. Incubator 1991. URL: http://1991.vc/about/ 